\title{
Breast Milk Micronutrients in Lactating Mothers from Ribeirão Preto (SP), Brazil
}

\author{
Marco Túlio Soares Andrade1, Luiz Antonio Del Ciampo', Ieda Regina Lopes Del Ciampo1, \\ Ivan Savioli Ferraz' ${ }^{1}$, Fernando Barbosa Junior ${ }^{2}$ \\ ${ }^{1}$ Department of Puericulture and Pediatrics, Faculty of Medicine of Ribeirão Preto, University of São Paulo, \\ São Paulo, Brazil \\ ${ }^{2}$ Department of Clinical, Toxicological and Bromatological Analyses, Faculty of Pharmaceutical Sciences of \\ Ribeirão Preto, University of São Paulo, São Paulo, Brazil \\ Email: delciamp@fmrp.usp.br
}

Received 22 April 2014; revised 29 May 2014; accepted 10 June 2014

Copyright (C) 2014 by authors and Scientific Research Publishing Inc.

This work is licensed under the Creative Commons Attribution International License (CC BY).

http://creativecommons.org/licenses/by/4.0/

(c) (i) Open Access

\begin{abstract}
Breast milk is the ideal food for infants and should be consumed as the exclusive food for the first six months and then be complemented up to two years of age. The aim of this study is to determine breast milk's content of macro and micronutrient in lactating mothers from the Ribeirão Preto (SP) region, in Brazil. A cross-sectional study was conducted with breast milk samples of 70 mothers from the city of Ribeirão Preto (SP). The samples were analyzed in order to determine iron, copper, zinc, calcium and magnesium concentrations. They were analyzed by Inductively Coupled Plasma Mass Spectrometry (ICP-MS). The study was approved by the Research Ethics Committee of the University Hospital, Faculty of Medicine of Ribeirão Preto, University of São Paulo, and all subjects gave written informed consent to participate. The current study revealed that all 70 lactating mothers were healthy and delivered babies more than 38 weeks gestation; $71.4 \%$ of them were younger than 30 years and $47.1 \%$ were primiparae. The iron, copper, zinc, calcium and magnesium concentrations detected in milk were $2.7 \pm 0.4,0.4 \pm 0.02,3.6 \pm 0.2,142 \pm 21.6$ and $39.8 \pm 4.2$ $\mathrm{mg} / \mathrm{L}$, respectively. Therefore, it can be concluded that in the present sample, except for calcium, all other mineral concentrations were adequate for the infant's requirements according to the Dietary Reference Intake (DRI).
\end{abstract}

\section{Keywords}

Human Milk, Breastfeeding, Micronutrients, Micronutrients, ICP-MS

\section{Introduction}

Breast milk is the ideal food for infants and should be consumed as the exclusive food for the first six months

How to cite this paper: Andrade, M.T.S., Del Ciampo, L.A., Del Ciampo, I.R.L., Ferraz, I.S. and Barbosa Junior, F. (2014) Breast Milk Micronutrients in Lactating Mothers from Ribeirão Preto (SP), Brazil. Food and Nutrition Sciences, 5, $1196-1201$. http://dx.doi.org/10.4236/fns.2014.513130 
and then be complemented up to two years of age. This is a living food of dynamic composition which contains all nutrients necessary for growth and development of the lactating baby, in addition to offering protective elements against infections, allergies and chronic-degenerative diseases [1].

The composition of maternal milk is frequently modified according to the time of day, duration of feeding and time of lactation, as well as the parity and nutritional status of the mother, being also influenced by genetic and environmental conditions [1] [2]. Regarding the volume produced, the estimate is that intake will increase, on average, from $600 \mathrm{ml} /$ day during the first four weeks of life to $820 \mathrm{ml} /$ day in the fourth month of life [3] [4].

Minerals are very important elements for the organism since they are related to numerous enzymatic systems, acting on immunological function and gene expression, in addition to playing an obvious role in growth and development. During the first months of life, breast milk is the only source that satisfies the requirements of the nursing baby. Among the main minerals of interest for human health are iron, calcium, zinc, magnesium, and copper. Deficiency of these minerals can cause many problems for the children, specially retarded physical growth and cognitive performance, poor bone development and changes in the transmission of nerve impulses, with impaired immunological function and changes in enzymatic systems, myelinization and hemoglobin [5]-[7].

The mammary gland is a highly differentiated structure functioning by means of endocrine and neurohormonal controls, which prepares itself during pregnancy to provide a product of excellent quality for the infant. Some mechanisms regulating the concentrations of minerals are found in the gland, acting both on the uptake of mineral from serum and on the synthesis and secretion of milk by the cells, leading to wide variations in the composition and volume of milk [8] [9].

In view of the importance of maternal milk for children, exclusive breastfeeding should be encouraged during the first six months of life. It is also very important and necessary to determine the mineral content of mothers' milk in order to provide a supply of all the elements necessary for the growth and development of nursing infants [10].

In this context, the objective of the present study was to determine the iron, zinc, copper, magnesium and calcium content in the breast milk of mothers whose babies are seen at a primary care service for mothers and infants in the city of Ribeirão Preto (SP).

\section{Methodology}

a) Experimental design: a cross-sectional, observational and descriptive study was conducted from April 1 to September 30, 2011 on 70 healthy women (minimum age $=16$ years, maximum age $=39$ years) who were exclusively breastfeeding their babies, younger than 6 months. All infants were enrolled in the Puericulture Program of a primary health care unit for mothers and infants in the city of Ribeirão Preto, State of São Paulo, Brazil. Each participant offered a $5 \mathrm{ml}$ sample of milk collected manually from a breast previously cleaned with cotton wool and distilled water. The milk sample was transferred to a Falcon ${ }^{\circledR}$ BD polyethylene tube and stored at $-20^{\circ} \mathrm{C}$, being later thawed at room temperature for triplicate analysis. All analyzes were performed after completion of all 70 samples in the laboratories of the Faculty of Pharmaceutical Sciences of Ribeirão Preto, University of São Paulo (USP). The study was approved by the Ethics Committee of the University Hospital, Faculty of Medicine of Ribeirão Preto, USP. The mothers were informed about the purpose of the study and written consent was obtained from all participants.

b) Macro and micronutrients determination by ICP-MS

Mineral concentrations were determined by inductively coupled plasma mass spectrometry (ICP-MS, ELAN DRC II, Perkin Elmer Sciex, Shelton, IL, USA) with the samples being submitted to microwave-assisted acid digestion in a closed system. The analyses were carried out using an ICP spectrometer equipped with a reaction cell (DRC-ICP-MS, ELAN DRCII, PerkinElmer, SCIEX, Norwalk, CT, USA) operating with ultrapure argon (99.999\%, Praxaair, Brazil). The sample introduction system consisted of a quartz cyclonic spray chamber and a Meinhard $^{\circledR}$ nebulizer connected by Tygon ${ }^{\circledR}$ tubes to the persistaltic pump of the ICP-MS (adjusted for 20 rpm). The ICP-MS operated with a sampling cone and Pt skimmer from PerkinElmer.

The milk samples (100 - $250 \mathrm{mg}$ ) were digested with $4 \mathrm{ml} 14 \mathrm{M}$ nitric acid $+2 \mathrm{ml} 30 \%$ hydrogen peroxide. The reference material NIST 8435-Whole Milk Powder and blood reference materials of the Canadian National Institute of Public Health and of the New York Health Department were used to determine the accuracy and precision of the method. 
c) Questionnaire: the mothers also answered a questionnaire concerning sociodemographic aspects such as age ( $<20,20$ to 30 , and $>30$ years), educational level, number of children, current health status, use of medications, vitamins or food supplements and habits such as smoking and the consumption of alcoholic drinks.

d) Reagents and solutions: high purity deionized water (resistivity: $18.2 \mathrm{Mcm}^{-1}$ ) for the preparation of samples an dilutions was obtained using a Milli-Q water purifying system (Millipore RiOs-DI TM, Bedford, MA, USA). All reagents used were analytical grade except $\mathrm{HNO}_{3}$, which was sub-distilled with a quartz distiller (Kürner Analysentechnik) before use. The solutions were prepared in a class 1000 clean room under a laminar flow hood. Rhodium $(1000 \mathrm{mg} / \mathrm{L})$ and multielement solutions $(10 \mathrm{mg} / \mathrm{L})$ were purchased from PerkinElmer (Shelton, CT, USA). Triton ${ }^{\circledR}$ X-100 was purchased from Sigma-Aldrich (St. Louis, MO, USA). All materials were first decontaminated in $15 \%(\mathrm{v} / \mathrm{v}) \mathrm{HNO}_{3}$ for $24 \mathrm{~h}$, washed five times with Milli-Q water, and dried under a laminar flow hood before use.

e) Statistical analyzes: descriptive analysis to check the distribution of the data, estimates of frequency, percentages and measures of central tendency and standard deviation was performed. The statistical package used was SPSS 10.0.

\section{Results and Discussion}

Breast milk samples from 70 mothers of babies born at term were analyzed. The mothers reported to be healthy and not to take medications, vitamins or nutritional supplements; $71.4 \%$ of them were younger than 30 years, 47.1\% were primiparous, $74.3 \%$ were nonsmokers, and all denied consumption of alcoholic drinks, as presented in Table 1. Regarding the age distribution of the nursing infants, there was a predominance of less than 1 month of life (31.4\%), while $20 \%$ were 1 to 2 months old and $17.1 \%$ were 3 to 4 months old.

Mean, median, maximum and minimum concentrations $(\mathrm{mg} / \mathrm{L})$ and $95 \%$ confidence intervals of macro and micronutrients of the lactating women, as well as the minimum daily requirements of these minerals according to the Dietary Reference Intake (DRI) of the Institute of Medicine [11] are shown in Table 2.

During the first semester of life, infants in good condition have a high weight gain and growth rate, doubling their birth weight by about the 5th month of life. To this end, they must obtain from their food adequate quantities of all nutrients under the proper conditions of utilization. Among the references most extensively used for this evaluation are the DRI tables elaborated by the Institute of Medicine of the National Academy of Sciences of the United States and used all over the world for several years [11]. In case of exclusively breastfed babies,

Table 1. Distribution of the sociodemographic variables of the 70 lactating mothers. Ribeirão Preto, 2011.

\begin{tabular}{|c|c|c|}
\hline Maternal variables & Number of mothers & Frequency (\%) \\
\hline \multicolumn{3}{|l|}{ Age (years) } \\
\hline Up to 20 & 14 & 20.0 \\
\hline 20 to 30 & 36 & 51.4 \\
\hline$>30$ & 20 & 28.6 \\
\hline \multicolumn{3}{|l|}{ Number of children } \\
\hline 1 & 33 & 47.1 \\
\hline 2 & 14 & 20.0 \\
\hline 3 & 14 & 20.0 \\
\hline$\geq 4$ & 9 & 12.9 \\
\hline \multicolumn{3}{|l|}{ Smoking habit } \\
\hline No & 52 & 74.3 \\
\hline Yes & 18 & 25.7 \\
\hline \multicolumn{3}{|c|}{ Alcoholic drink consumption } \\
\hline No & 70 & 100.0 \\
\hline
\end{tabular}


Table 2. Mean, median, maximum and minimum concentrations (mg/L), 95\% confidence interval and daily requirements of calcium, copper, iron, magnesium and zinc. Ribeirão Preto, 2011.

\begin{tabular}{ccccccc}
\hline & minimum & maximum & mean \pm SD & median & 95\% CI & Daily requirements (mg) $^{*}$ \\
\hline Calcium & 90.85 & 188.3 & $142.3 \pm 21.6$ & 144.2 & $138.1-148.2$ & 210 \\
Copper & 0.15 & 1.37 & $0.4 \pm 0.02$ & 0.42 & $0.396-0.404$ & 0.20 \\
Iron & 1.97 & 3.69 & $2.7 \pm 0.4$ & 2.65 & 2.612 .79 & 0.27 \\
Magnesium & 20.40 & 52.1 & $39.8 \pm 4.2$ & 34.96 & $38.8-40.7$ & 30.0 \\
Zinc & 2.19 & 9.88 & $3.6 \pm 0.2$ & 2.50 & $3.55-3.64$ & 2.0 \\
\hline
\end{tabular}

$\mathrm{SD}=$ standard deviation; $\mathrm{CI}=$ confidence interval; ${ }^{*}$ Dietary Reference Intake.

the quantities of the elements listed in the tables must be contained in the daily volume of maternal milk ingested by the infants, which is very difficult to quantify. In general, a lactating woman in good health can produce 640 to $820 \mathrm{~mL}$ of milk per day, an amount that fully satisfies most of the babies born at term during this period of life [12].

Regarding the mean mineral concentrations obtained in the present study, it can be seen that, except for calcium, the remaining elements present in breast milk could satisfy the daily requirements of the infants during the first semester of life. However, if we consider the milk volume produced daily by the mother to be $800 \mathrm{~mL}$, these ingested quantities would be insufficient for $18.5 \%$ (13/70) of the infants regarding copper, for $44.2 \%$ (31/70) regarding zinc and for 64.2\% (45/70) regarding magnesium. Iron concentrations would be sufficient in all cases, while calcium concentrations would be below the daily requirements of the babies.

It is known that, in general, lactating women secrete 300 to $400 \mathrm{mg}$ calcium per day [13]. In the present study, the mean calcium concentration detected in the milk samples was $142.3 \pm 21.6 \mathrm{mg} / \mathrm{L}$, a value below the daily requirements of the infant. A similar result was obtained in Gambia in a study in which milk samples from 30 lactating women were analyzed at 3 months of lactation [14]. On the other hand, analyses of breast milk samples obtained during the first week of lactation in China [15] and in Ethiopia [16] revealed higher calcium concentrations than those detected here, i.e., $300 \mathrm{mg} / \mathrm{L}$ and $758 \mathrm{mg} / \mathrm{l}$, respectively. Studies conducted by Itriago et al. in Venezuela [17] and by Deng et al. in China [18] on mature milk samples detected lower calcium concentrations (244 mg/L and $280 \mathrm{mg} / \mathrm{L}$, respectively). These results demonstrate that the presence of this mineral in milk undergoes variations, because calcium content in breast milk does not correspond to the concentration in maternal serum. Thus, calcium homeostasis in the maternal organism during lactation is a complex process destined to protect the nursing infant and regulated by the mammary gland, involving deposits of bone tissue [19].

A characteristic of maternal milk is the high bioavailability of iron and zinc even though the concentrations of these minerals are known to decrease during the first months of lactation [1] [20]. The iron concentration detected in the present study was $2.7 \pm 0.4 \mathrm{mg} / \mathrm{L}$, above the daily recommended requirements for infants. Similar findings were obtained in studies conducted in the United States on 48 milk samples collected during the third month of lactation [21], and in studies conducted in Turkey during the second week of breastfeeding [22] and in Vietnam, in which iron concentrations exceeded the daily requirements of the infants [23].

The mean zinc concentration detected in the present study was $3.6 \pm 0.2 \mathrm{mg} / \mathrm{L}$, also above the requirements of the infant. Likewise as observed for iron, zinc concentrations exceeded the requirements also among American and Turkish lactating women. Studies conducted in Libya and in Sweden analyzed mature milk samples and detected concentrations of $4.95 \pm 1.3 \mathrm{mg} / \mathrm{L}$ and $3.4 \pm 0.9 \mathrm{mg} / \mathrm{L}$, respectively [10] [24]. In contrast, Fransson et al. [25], Mahdavi et al. [26], Orun et al. [27] and Winiarska-Mieczan [28] detected deficient zinc concentrations among Swedish, Iranian, Turkish and Polish lactating women, respectively. Adequate zinc and copper concentrations were detected in a Brazilian study in which 145 mature milk samples from lactating women aged 16 to 41 years were analyzed [29].

The mean copper concentration detected in the present study was $0.4 \pm 0.02 \mathrm{mg} / \mathrm{L}$, practically double the daily requirements of the infants during this phase of life. Similar findings were obtained in a study conducted in China on 120 lactating primiparous during the second week of breastfeeding [15], and in Portugal [30], Iran [26] and Sweden [24] in milk samples collected after the third week of lactation. On the other hand, another study also conducted in China on 60 women aged 20 to 35 years during the second month of lactation detected low 
copper concentrations, the same being observed among 95 Greek lactating women during the second week of breastfeeding [18] [31].

The magnesium concentration in human milk seems to be constant over the period of lactation [32]. While the mean magnesium concentration in the milk of mothers of Ribeirão Preto was $39.8 \pm 4.2 \mathrm{mg} / \mathrm{L}$, a value above the daily requirements of the baby, Itriago et al. [17] in Venezuela and Bjorklund et al. [24] in Sweden and Morgano et al. [33] in Brazil detected lower levels of this metal in mature milk samples, underscoring the wide variability of the data obtained in various studies on the constituents of breast milk.

On the basis of the present study, despite the limitations due to the small number of samples and of lactating women residing in a determined geographical area, we may conclude that breast milk contains adequate quantities of iron, zinc, magnesium and copper and insufficient quantities of calcium. The wide variability of breast milk composition, especially in mineral content, suggests which are affected by genetic, socioeconomic and environmental influences, suggesting a relationship between the concentrations of these elements in milk and the nutritional status of the lactating woman [34]. Studies of this type can contribute to an increased practice of breastfeeding by identifying maternal nutritional deficits and permitting the provision of a complete food to the infant during its first months of life.

\section{References}

[1] Picciano, M.F. (2001) Nutrient Composition of Human Milk. Pediatric Clinics of North America, 48, 53-67. http://dx.doi.org/10.1016/S0031-3955(05)70285-6

[2] Tackoen, M. (2012) Le Lait Maternel: Composition Nutritionnelle et Propriétés Fonctionnelles. Revue Medicale de Bruxelles, 33, 309-317.

[3] Ballard, O. and Morrow, A.L. (2013) Human Milk Composition. Nutrients and bioactive factors. Pediatric Clinics of North America, 1, 49-74. http://dx.doi.org/10.1016/j.pcl.2012.10.002

[4] Costa, T.H.M., Haisma, H., Wells, J.C.K., Mander, A.P., Whitehead, R.G. and Bluck, L.J.C. (2010) How Much Human Milk Do Infants Consume? Data from 12 Countries Using a Standardized Stable Isotope Methodology. Journal of Nutrology, 140, 2227-2232.

[5] Domellof, M., Lounerdal, B.L., Dewey, K.G., Cohen, R.J. and Hernell, O. (2004) Iron, Zinc and Copper Concentrations in Breast Milk Are Independent of Maternal Mineral Status. American Journal of Clinical Nutrition, 79, 111-115.

[6] Soetan, K.O., Olaiya, C.O. and Oyewole, O.E. (2010) The Importance of Mineral Elements for Humans, Domestic Animals and Plants. African Journal of Food Sciences, 4, 220-222.

[7] Tawia, S. (2012) Iron and Exclusive Breastfeeding. Breastfeeding Review, 20, 35-47.

[8] Kent, J.C., Prime, D.K. and Garbin, C.P. (2012) Principles for Maintaining or Increasing Breast Milk Production. Journal of Obstetric, Gynecologic, \& Neonatal Nursing, 41, 114-121.

[9] Stam, J., Sauer, J.J. and Boehm, G. (2013) Can We Define an Infant's Need from the Composition of Human Milk? American Journal of Clinical Nutrition, 98, 512S-518S.

[10] Hanna, M.A., Dogadkin, N.N., Ashur, I.A. and Markus, W.M. (2005) Copper, Selenium and Zinc Concentrations in Human Milk during the First Three Weeks of Lactation. Biological Trace Element Research, 107, 11-23. http://dx.doi.org/10.1385/BTER:107:1:011

[11] Institute of Medicine (2006) Dietary Reference Intakes; the Essential Guide to Nutrient Requirements. National Academy Press, Washington DC.

[12] Del Ciampo, L.A., Ricco, R.G. and Almeida, C.A.N. (2004) Aleitamento Materno. Passagens e Transferências MãeFilho. Editora Atheneu, Rio de Janeiro.

[13] VanHouten, J.N. and Wysolmerski, J.J. (2013) The Calcium-Sensing Receptor in the Breast. Best Practice \& Research Clinical Endocrinology \& Metabolism, 27, 403-414. http://dx.doi.org/10.1016/j.beem.2013.02.011

[14] Jarjou, L.M.A., Goldberg, G.R., Coward, W.A. and Prentice, A. (2012) Calcium Intake of Rural Gambian Infants: A Quantitative Study of the Relative Contributions of Breast Milk and Complementary Foods at 3 and 12 Months of Age. European Journal of Clinical Nutrition, 66, 673-677. http://dx.doi.org/10.1038/ejcn.2012.7

[15] Qian, J., Chen, T., Lu, W., Wu, S. and Zhu, J. (2010) Breast Milk Macro and Micro Composition in Lactating Mothers from Suburban and Urban Shanghai. Journal of Pediatrics and Child Health, 46, 115-120. http://dx.doi.org/10.1111/j.1440-1754.2009.01648.x

[16] Maru, M., Birhanu, T. and Tessema, D.A. (2013) Calcium, Magnesium, Iron, Zinc and Copper Compositions of Human Milk from Populations with Cereal and 'Enset' Based Diets. Ethiopian Journal of Health Sciences, 23, 90-97.

[17] Itriago, A., Carrión, N., Fernández, A., Puig, M. and Dini, E. (1997) Zinc, Copper, Iron, Calcium, Phosphorus and 
Magnesium Content of Maternal Milk during the First 3 Weeks of Lactation. Archivos Latinoamericanos de Nutrición, 47, 14-22.

[18] Deng, B., Zhang, H., Yan, C. and Zhang, L. (2009) Levels of Mineral Elements Composition and Heavy Metal Pollution in Human Breast Milk in Shenzhen City. Wei Sheng Yan Jiu, 38, 293-295.

[19] Olausson, H., Goldberg, G., Laskey, M.A., Schoenmakers, I., Jarjou, L.M.A. and Prentice, A. (2012) Calcium Economy in Human Pregnancy and Lactation. Nutrition Research Reviews, 25, 40-67. http://dx.doi.org/10.1017/S0954422411000187

[20] Dorea, J.G. (2012) Zinc and Copper Concentrations in Breast Milk. Indian Pediatrics, 49, 592. http://dx.doi.org/10.1007/s13312-012-0107-4

[21] Hannan, M.A., Faraji, B., Tanguma, J., Longoria, N. and Rodriguez, R.C. (2009) Maternal Milk Concentration of Zinc, Iron, Selenium and Iodine and Its Relationship to Dietary Intakes. Biological Trace Element Research, 127, 6-15. http://dx.doi.org/10.1007/s12011-008-8221-9

[22] Yalem, S.S., Baykan, A., Yurdakok, K., Ualen, S. and Gucus, A.I. (2009) The Factors that Affect Milk-to-Serum Ratio for Iron during Early Lactation. Journal of Pediatric Hematology and Oncology, 31, 85-90. http://dx.doi.org/10.1097/MPH.0b013e31819146c2

[23] Nakamori, M., Ninh, N.X., Isomura, H., Yoshike, N., Hien, V.T.T., Nhug, B.T., et al. (2009) Nutritional Status of Lactating Mothers and Their Breast Milk Concentration of Iron, Zinc and Copper in Rural Vietnam. Journal of Nutritional Science and Vitaminology, 55, 338-345. http://dx.doi.org/10.3177/jnsv.55.338

[24] Bjorklund, K.L., Vahter, M., Palm, B., Grandér, M., Lignell, S. and Berglund, M. (2012) Metals and Trace Element Concentrations in Breast Milk of First Healthy Mothers: A Biological Monitoring Study. Environmental Health, 11, 92-99. http://dx.doi.org/10.1186/1476-069X-11-92

[25] Fransson, G. and Lonnerdal, B. (1882) Zinc, Copper, Calcium and Magnesium in Human Milk. The Journal of Pediatrics, 101, 504-508. http://dx.doi.org/10.1016/S0022-3476(82)80690-2

[26] Mahdavi, R., Nikniaz, L. and Gayemmagami, S.J. (2010) Association between Zinc, Copper and Iron Concentrations in Breast Milk and Growth of Healthy Infants in Tabriz, Iran. Biological Trace Element Research, 135, 174-181. http://dx.doi.org/10.1007/s12011-009-8510-y

[27] Orun, E., Yalçin, S.S., AIkut, O., Orhan, G. and Morgil, G.K. (2012) Zinc and Copper Concentrations in Breastmilk at the Second Month of Lactation. Indian Pediatrics, 49, 133-135. http://dx.doi.org/10.1007/s13312-012-0021-9

[28] Winiarska-Mieczan, A. (2014) Cadmiun, Lead, Copper and Zinc in Breast Milk in Poland. Biological Trace Element Research, 157, 36-44. http://dx.doi.org/10.1007/s12011-013-9870-x

[29] Mello-Neto, J., Rondó, P.H.C., Oshiiwa, M., Morgano, M.A., Zacari, C.Z. and Santos, M.L. (2013) Iron Supplementation in Pregnancy and Breastfeeding and Iron, Copper and Zinc Status of Lactating Women from a Human Milk Bank. Journal of Tropical Pediatrics, 59, 140-144. http://dx.doi.org/10.1093/tropej/fms055

[30] Almeida, A.A., Lopes, C.M.P.V., Silva, A.M.S. and Barrado, E. (2008) Trace Elements in Human Milk: Correlation with Blood Levels, Inter-Element Correlations and Changes in Concentration during the First Month of Lactation. Journal of Trace Elements in Medicine and Biology, 22, 196-205. http://dx.doi.org/10.1016/j.jtemb.2008.03.007

[31] Leotsinidis, M., Alexopoulos, A. and Kostopoulou-Farri, E. (2005) Toxic and Essential Trace Elements in Human Milk from Greek Lactating Women: Association with Dietary Habits and Other Factors. Chemospehre, 61, 238-247. http://dx.doi.org/10.1016/j.chemosphere.2005.01.084

[32] Dórea, J.G. (2000) Oral Contraceptives Do Not Affect Magnesium in Breast Milk. International Journal of Gynecology and Obstetrics, 71, 25-31. http://dx.doi.org/10.1016/S0020-7292(00)00193-4

[33] Morgano, M.A., Souza, L.A., Neto, J.M. and Rondó, P.H.C. (2005) Composição Mineral do Leite Materno em Bancos de Leite. Ciência e Tecnologia de Alimentos, 25, 819-824. http://dx.doi.org/10.1590/S0101-20612005000400031

[34] Parr, R.M., DeMayer, E.M., Iyengar, V.G., Byrne, A.R., Kirkbright, G.F., Schoch, G., et al. (1991) Minor and Trace Elements in Human Milk from Guatemala, Hungary, Nigeria, Philippines, Sweden and Zaire. Biological Trace Element Research, 29, 51-75. http://dx.doi.org/10.1007/BF03032674 
Scientific Research Publishing (SCIRP) is one of the largest Open Access journal publishers. It is currently publishing more than 200 open access, online, peer-reviewed journals covering a wide range of academic disciplines. SCIRP serves the worldwide academic communities and contributes to the progress and application of science with its publication.

Other selected journals from SCIRP are listed as below. Submit your manuscript to us via either submit@scirp.org or Online Submission Portal.
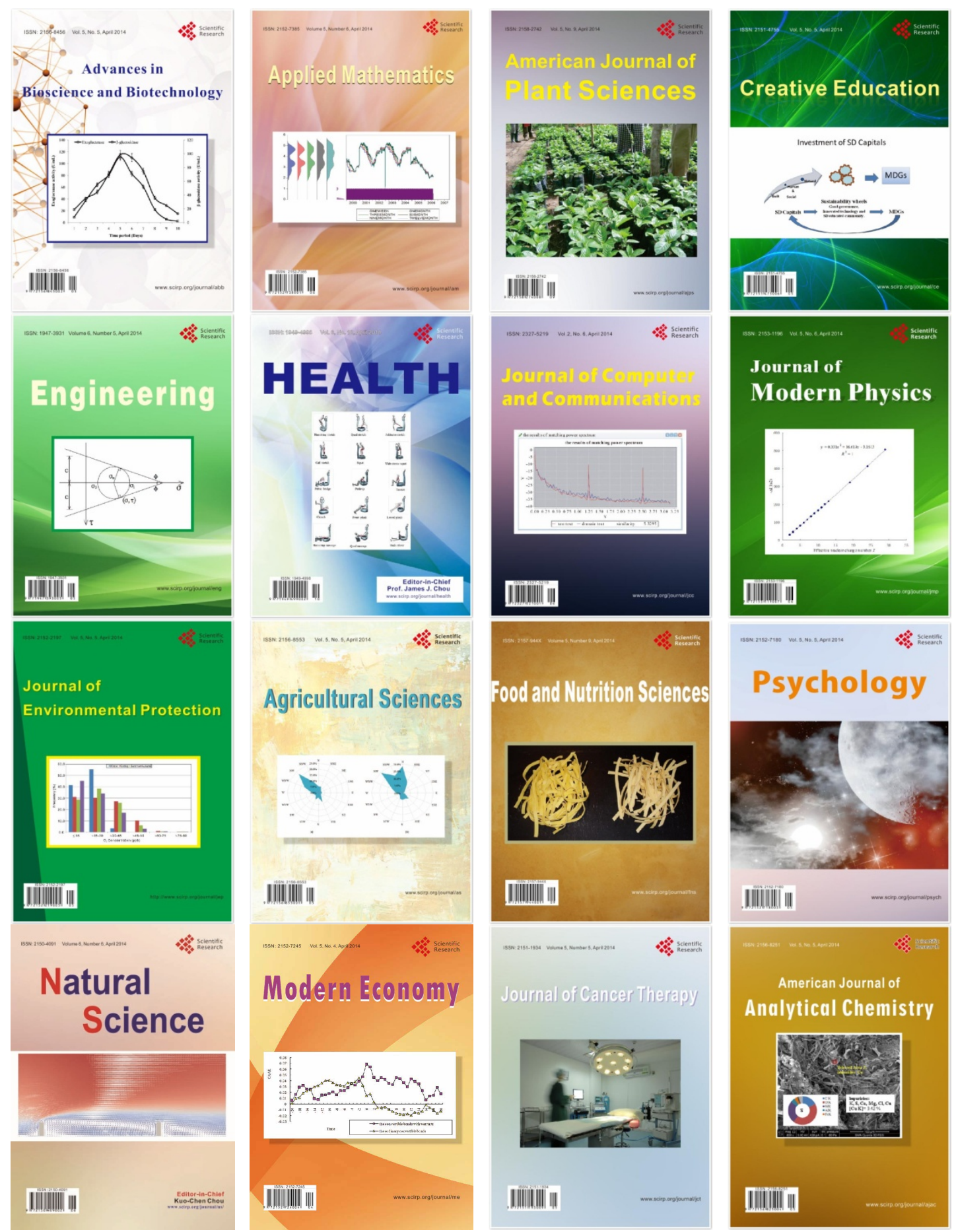